\title{
Response to Comments on Priest of Nature
}

\author{
Rob Iliffe \\ University of Oxford, Oxford, UK \\ robert.iliffe@linacre.ox.ac.uk
}

I am grateful to the contributors of this forum for offering their responses to Priest of Nature. Steffen Ducheyne's remarks on the degree of interconnectedness between Newton's various activities concern a topic that lies at the heart of the book and underpins most of my other writings on Newton. As I showed in the book, Newton made a number of distinctions between the types of procedures that were applicable to his scientific-mathematical and religious enquiries. This division was sustained and reinforced by editorial and curatorial decisions that began in the immediate aftermath of his death, but the archive was only formally partitioned when Lord Portsmouth made his munificent bequest of Newton's scientific and mathematical papers to Cambridge University at the end of the nineteenth century. In the decades following the end of the Second World War, historians of Newton's work in the exact sciences had the benefit of various printed editions of his most significant works, while those interested in his alchemical writings had to consult the Keynes papers in King's College Cambridge. The Yahuda papers in the Jewish and National University Library in Jerusalem, which contained the vast majority of his religious writings, were made available for study at the start of the 1970s, but the non-scientific papers only became widely accessible on microfilm in the early 198 os. ${ }^{1}$

When I began my research on the papers in the mid-1980s, the Newton 'industry' was a divided kingdom. In one corner stood more positivisticallyinclined scholars who studied Newton's work in the exact sciences, and to most of them Newton's writings on alchemy and theology amounted to a derangement of the intellect. In another corner were historians such as Betty Dobbs and Frank Manuel who tended to see all of Newton's endeavours as connected either by conceptual or methodological interests, or by the fact that they all emanated from his mind (or his quill). Between these positions were

1 For the fate of Newton's archive, see Sarah Dry, The Newton Papers: The Strange and true Odyssey of Isaac Newton's Manuscripts, (New York, 2014). 
a few philosophically-oriented historians, or historically-informed philosophers, notably Alexandre Koyré and Ted McGuire, who focussed on what could broadly be called Newton's metaphysical theology and his philosophy of science. Although their essays drew on a diverse set of Newton's papers, the subject matter of their research covered only a very limited aspect of his religious writings. In part this was because only a handful of texts from Newton's analysis of prophecy or church history was then available, but these texts were irrelevant or tangential to their arguments. Even when the extraordinary Jerusalem treasure trove was opened up, only two scholars (Manuel and Richard Westfall) made more than a cursory examination of its contents. ${ }^{2}$

I initially decided to engage with these papers in part because they were there, and in part, because the task was hard. In due course, I realized that Newton's theological writings had to be related in a general sense to his work in natural philosophy, and decided that there were more obvious differences between them than there were connections. In Priest of Nature, I identified those subject distinctions in Newton's work that he implicitly endorsed, explicitly counselled and exemplified in his papers, and explained how he maintained these divisions by appealing to the respective disciplinary norms, argumentative styles, and types of evidence that were appropriate to each domain. Where I did point to consonances between his theological writings and other areas of his work, these were conclusions derived from evidence in the texts themselves, rather than assumptions derived from some crude $a$ priori position that was then lazily applied to the sources. Only after presenting a substantial amount of evidence did I invoke as the cause of some of his intellectual decisions a few of the obvious psychological (many said pathological) features of his 'personality' to which both his friends and enemies alluded.

Regarding any similarities in research techniques and practices that Newton adopted in his work on prophecy and natural philosophy, I tried to distinguish carefully between his methodological stipulations about ideal practice, and what he actually did. It is trivially easy to find such similarities between Newton's prescription-talk in these fields. For example, he frequently intoned that one should prefer the most simple explanations, rely on properly marshalled evidence, and avoid passing off speculations as certainties. Yet there were evidently pertinent differences in practice between these fields, and it is clearly fruitful to compare and contrast the various ways in which he garnered evidence in the service of defending or rebutting theoretical claims in distinct research programmes. On this topic, I agree with Ducheyne that there is much

2 See Frank Manuel, The Religion of Isaac Newton, (Oxford, 1974) and Richard Westfall, Never at Rest: A Biography of Isaac Newton (Cambridge, 1980). 
more to be said about Newton's efforts over many decades to harmonize his theoretical schema in prophecy and natural philosophy with supporting data that he adduced for the purpose. I should certainly have said something about the various ordering procedures he used to assess the credibility of alchemical authors, Biblical writers and church historians (and, by extension, the credibility of their writings).

A second issue, raised by Mandelbrote, concerns the methods of dating Newton's manuscripts and research projects, as well as the confidence historians can have in these dates. In opposition to those historians who have attempted to chronologically order Newton's manuscripts according to their own pre-fabricated conceptual schemes, or who have claimed to be able to date manuscripts by sight, I was cautious about assigning dates without offering sound arguments and providing robust evidence in support. As all serious students of Newton's work are aware, there are well-known signposts for doing this, especially in terms of the termini ante quos provided by textual references to identifiable published books, evidence of the use by Newton of his own books, dated correspondence, and the handwriting of his amanuensis Humphrey Newton. The scrutiny of watermarks, countermarks or the use of inks, which can then be connected to datable documents, can provide further precision in terms of assigning dates to texts, and equally, the research infrastructure underpinning what are oxymoronically termed the 'digital materials' can allow the reader to easily place works in chronological order. Future scholars who are serious about drilling down into Newton's quotidian research practices will routinely combine analysis of the physical materials with the use of the digital edition of his work. Here is the place to point to the possibilities for research provided by current advances in machine-learning, which is already able to provide extraordinary support for the editorial organisation of the digital materials. ${ }^{3}$

A third point, noted with dismay by many reviewers, is that my analysis effectively stopped at the point where Newton left to live and work full-time in London in the mid-169os. This was unfortunate, given that much of Newton's most accessible work, including all of his general and explicit musings on the proper relationship between church and state (such as assertions concerning the latitudinarian foundations of the Church of England) dates from the early eighteenth-century. One explanation for finishing in the late 169 os is bound

3 For an early effort to date some of Newton's paper through watermark and countermark analysis, see Alan E. Shapiro, "Beyond the Dating Game: Watermark Clusters and the Composition of Newton's Opticks," in The Investigation of Difficult Things, ed. Peter M. Harman and Alan E. Shapiro (Cambridge, 1992), 181-227. 
up with the advent of the Newton Project at the end of the 199os. Having produced a draft of a book on Newton's religious life and work over his entire career, the existence of the Project transcriptions allowed me to give a much more detailed account than I had envisaged of the content of his early theological enquiries. With this data at my disposal, I could track the minute development of Newton's thought through successive drafts and mutations in larger projects, but I was also in a better position to situate this work in its wider intellectual social and political contexts. As I suggested above, a central goal in writing the book was to get away from the perceived obligation to legitimate, or even understand his religious writings in terms of his writings in natural philosophy. While this is obviously of great interest, the appropriate historical settings for understanding and explaining Newton's theological research were the broader social and intellectual issues that Paul Hazard summarised under the heading "The Crisis of the European Mind". ${ }^{4}$

A second explanation, a consequence of the first, is that I envisaged writing a second volume devoted to the latter period of Newton's life (provisionally entitled 'Lord of All'), when he was a major public figure and official, and to some extent leading a life in contrast with his earlier, retiring collegiate self. Newton gained a wide reputation for his religiosity at the same time as he revealed his potentially explosive theological work to trustworthy followers such as Samuel Clarke and William Whiston, although ironically he was soon tainted by his proximity to them. While his secretiveness was of course characteristic of every domain of his work, his restricted dissemination of the theological materials had to be managed in different ways from, say, his alchemical and mathematical writings, or his speculative ideas in natural philosophy. The publication of the 'sensorium' queries in Optice in 1706, and the marginally less terse theological statements in the 'General Scholium' of 1713 attracted the often unwelcome attention of suspicious commentators, but the vast majority of readers saw nothing heterodox in them. Unless one was a close friend or confidant of Newton, or primed to see through (or read into) these meagre published offerings, there was little evidence of anything untoward about his religious opinions. That said, the abuse directed against him by a group of over a hundred students for 'occasional conformity' during his candidacy for the parliamentary elections in 1705 is obviously indicative of wider concerns about

4 See Paul Hazard, The Crisis of the European Mind (New York, 2013, orig. 1935). The claim that one needs to invoke the Scientific Revolution in order to understand the radical nature of Newton's theological ideas is, of course, absurd. 
his orthodoxy. In any case, behind the scenes, his heterodox research and writing continued apace. ${ }^{5}$

Debates over the nature of the doctrine of the Trinity, its evidential basis, and what to do with those brave enough to publicly deny it, continued to rage in the early eighteenth century. Newton never gave up his considered view that the orthodox doctrine of the Trinity was an abomination, and although there was vigorous disagreement about the Trinity doctrine inside the Anglican church, his views would have been unacceptable to the vast majority of religious elites. Continuing his study of prophecy and church history right up to the last year of his life, the child of the English Revolution remained committed to the genre of apocalyptic exegesis to which (as he saw it) Joseph Mede had contributed so much. Although he retained the basic prophetic schema and apocalyptically-charged account of the fourth- and fifth-century history of Christianity that I described in Priest of Nature, his heavily redrafted manuscripts show that he continued to finesse his prophetic views in the last three decades of his life. There was always one more supportive Scriptural text to incorporate into the general system, or one more piece of historical evidence to find. A dedicated scholar may well be able to show that Newton's work evolved to a much greater extent in his later years than is apparent at first glance.

As with much of his late-career work on prophecy, he copied either verbatim or with minor changes large sections of his own treatises on church history, notably those on the Arian controversy and its aftermath. Along with his prophetic writings, it is these manuscripts that so stupefied the Victorian scholars at Cambridge who set out to select the 'valuable' scientific and mathematical papers for posterity. Nevertheless, in the eighteenth-century Newton appears to have radically re-oriented his historical focus in order to concentrate on the origins of Christian apostasy. Frank Manuel was surely correct to observe that Newton was channelling his dislike of Leibniz in his attacks on the influx of 'metaphysicks' into early Christianity. Indeed, internal evidence indicates that the papers in which Newton directed his ire towards the metaphysical Cabbalists and filthy gnostics were composed in the second decade of the eighteenth century, at the same time as he was writing against Leibniz in various forms. More broadly, his analysis of the conduct and beliefs of Nazarenes, Ebionites and others in these early Christian societies provides the best evidence of what he took to be the key features of church-state relations in his

5 For the dissimulation and dissemination of his beliefs, see Larry Stewart, "Seeing through the Scholium: Religion and Reading Newton in the Eighteenth-Century," History of Science, 34 (1996), 123-165, and Stephen D. Snobelen, "Isaac Newton, Heretic, the Strategies of a Nicodemite," British Journal for the History of Science, 32 (1999), 381-419, esp. 401-408. 
own time, and merit much greater scholarly attention than they have received so far. ${ }^{6}$

Guicciardini's pertinent remarks regarding the political settings of the priority dispute with Leibniz are also worthy of comment. With the publication of all of Newton's Leibniz-related writings on the Newton Project there is now an unprecedented opportunity to ascertain what Newton was doing behind the scenes during the dispute, both before and after he 'entered the ring' or 'removed his mask' to strut on the public stage (as Leibniz and Johann Bernoulli put it). In Priest of Nature, I alluded to the various rhetorical features of the dispute, and pointed very briefly to the ways in which Newton's conduct was indebted to his general forensic approach to the analysis of historical documents. Newton's strenuous efforts to shift the argument on to the legalistic terrain is clear from the carefully crafted documentary structure of the Commercium Epistolicum and especially from the language of the 'priority dispute' manuscripts among the Portsmouth papers. However, it is equally visible in Leibniz's own correspondence, particularly with Hanoverian bureaucrats and courtiers, which shows how difficult it was for him to avoid being tried in the sham English court. His distance from his own papers and letters was deeply problematic for his chances in a documentary war, but he also failed to convince his German interlocutors in London that a different, more diplomatic route was more appropriate for deciding the issue of his honour. As for Guicciardini's view that there is much more to be said about the metaphysical commitments underpinning their various fluxional and differential calculuses, I agree, and can think of no one more able or qualified than Guicciardini himself to say it.

Historians have still barely scratched the surface of the political connections and intrigues in which the various sides to the priority dispute were enmeshed. With the earl of Halifax as his key patron, Newton's position as Master of the Mint and President of the Royal Society (among others) afforded him powerful contacts in successive administrative and courtly circles. He and Samuel Clarke moved quickly (and it turns out, successfully) to ingratiate themselves with the Hanoverian regime, while Leibniz was seriously disadvantaged by being so geographically remote from the new court of the prince-elector Georg Ludwig. It may be, as Guicciardini suggests, that the prospect of the would-be Christian unifier coming to London sent shivers down the spines of Anglican Newtonians. They knew of Leibniz's role in securing the Hanoverian succession, and Clarke, whom Caroline insisted would be one of her favourites almost

6 See Manuel, The Religion of Isaac Newton, 75-79; and Matt Goldish, Judaism in the Theology of Isaac Newton (Boston, MA-London, 1998), chs. 6-7. 
immediately after she arrived in London, was aware of Leibniz's suggestions for arranging matters so that the king's Lutheran practices could be made compatible with those in the Church of England. Given the very real threat posed by Jacobite rebels in 1714-1715, the Newtonians had good reason to fear the restoration of a pro-Catholic regime in their midst. Clarke may also have been privy to Leibniz's half-hearted protestations that he might become George I's royal historiographer, though he and Newton also knew that this was unlikely. This was both because Leibniz was under serious pressure to make headway with his history of the Guelphs, and also because recent naturalisation laws greatly limited the capacity of foreign monarchs to appoint their own favourites to paid positions. As it was, Leibniz's heart lay in Vienna. ${ }^{7}$

Despite his remoteness from London, Leibniz's political correspondence shows that he had excellent relations with a number of England-based individuals he had encountered at various times and places, largely as a result of the various placements he had held over his long diplomatic career. As something of a counterbalance to the increasingly fickle intellectual support given to him by Caroline and Antonio Conti, he had many friends among 'les Anglois' who did what they could. Amongst these one may include John Arnold, the medic and one-time student of Johann Bernoulli; the diplomat John Chamberlayne; the theologian David Wilkins (who briefly resided in Chamberlayne's house); the economic writer Simon Clement; and William Winde, who had been chamberlain to Princess Sophia. Many of them knew each other well, and they were prepared to defend the reputation of English fair play (as much as Leibniz himself) against the dastardly machinations of Newton, Clarke, Keill and others. German correspondents at the Hanoverian court were also significant informants regarding British intellectual culture. From 1714-1715 Leibniz was in close contact with Casper Hasberg (the secretary of the Wolfenbuttel Society of Arts and Sciences), who was then in London, and following Hasberg's departure he received regular and detailed information from Philipp Heinrich Zollman (governor to the children of Count von Bothmer and son of Leibniz's friend Johann Zollmann [sic]). No wonder then, that the President of the Royal

7 For Caroline, see Domenico Bertoloni Meli, "Caroline, Clarke and Leibniz," Journal of the History of Ideas, 6o (1999), 469-486 and Greg Brown, “.... et je serais tousjours la même pour vous': Personal, Political and Philosophical Dimensions of the Leibniz-Caroline Correspondence," in Leibniz and his Correspondents, ed. Paul Lodge (Cambridge, 2004), 262-292. As Caroline became intellectually and geographically distant from Leibniz, so she increasingly relied on Clarke and the newly appointed Archbishop of Canterbury, William Wake. For her support of Clarke, whose writings she called "the finest Things in the World", see the remarkable testimony in Diary of Mary Countess Cowper, Lady of the Bedchamber to the Princess of Wales 1714-1720 (London, 1864), 16-19. 
Society was privately obsessed with Leibniz's capacity to mobilise disciples and spies on English soil, not the least of whom was Leibniz's long-time technical advisor Justus von Brandshagen. ${ }^{8}$

As key English supporters of Leibniz, one should of course single out John Flamsteed and John Woodward, both of whom were in close contact with associates of the Hanoverian entourage such as Hasberg, and with Caroline herself. These men, whom one assumes never opened the pages of the Theodicée, needed no prompting in order to see that substantial harm came to the Newtonian cause. Woodward outdid himself in revealing Newton's key role in the priority dispute, pleading (when both sides found it convenient to pretend that Newton was above the fray) that it was Newton and not Keill, or the Royal Society itself, who was the driving force behind the attacks on Leibniz. Flamsteed took delight in showing glaring errors in the 1713 Principia Mathematica to Hasberg and others, and told Leibniz's allies that Newton had insufficient observational data to support his case. In the summer of 1716, after Caroline had become a convert to the Newtonian worldview, she related to Leibniz the gist of her recent visit to the Astronomer Royal in his Greenwich lair. "Sa maison et sa figure ont l'aire de Merlain," she wrote, and she noted that Flamsteed had told her that while Leibniz was a gentleman, Newton was a great rascal who had stolen two of his stars. She added that she could not prevent herself from laughing at the situation. Although she told the story of Flamsteed's support and Newton's chicanery in order to elevate Leibniz's 'troubled spirits', both the content and the tone of the letter betrayed her opinion that Merlin was not a serious advocate of Leibniz's case. More importantly, it was of a piece with her own view, and that of the king and senior courtiers, that the mathematical and philosophical disputes were unworthy of famous men, and indeed were wholly insignificant in comparison with the more serious business of writing the history of the Guelphs. ${ }^{9}$

Finally, I also want to re-emphasise the importance of attending to the technical content of Newton's theological studies, and to consider what this says about Newton the man. As Guicciardini perceptively notes, whatever else

8 For Zollman, see the fine article by Derek Massarella, "Philip Henry Zollman, the Royal Society's First Assistant Secretary for foreign correspondence," Notes and Records of the Royal Society of London, 46 (1992), 219-234. Massarella remarks (226) on Zollman's belated election as a Fellow of the Royal Society in June 1727 (he was admitted the following January), noting that this happened almost immediately after Newton's death. He is indulging in wishful thinking in suggesting that Newton was above blocking Zollman's election for his earlier association with Leibniz.

9 Caroline to Leibniz, 15/26 June 1716, in Onno Klopp, ed., Die Werke von Leibniz. Erste Reihe, 11 vols. (Berlin, 1864-1884), 11: 114-116. 
connects the various lines of enquiry in which Newton engaged, a common feature was his quest for membership of their respective 'guilds of practitioners'. As a result, those historians who want to understand what Newton was doing in any of these spheres need to dive into the technical content. As for theology, it is written for theologians (as Copernicus might have said), and Newton's intricate accounts of the relations between the visions of the vials, trumpets and seals were composed for theologically sophisticated readers (whoever they were). These details are not now to everyone's taste, and were barely more palatable in Newton's time, but the man and his ideas emerge most clearly only as a result of seriously considering these minutiae.

In his religious writings Newton's moral convictions and commitments reveal themselves to a much greater extent than in any other area of his life. Whether we like it or not, they show, as does evidence from those who knew him closely, that he saw himself as being on a mission from God. As Stephen Snobelen remarks in his comments, the Isaac Newton who authored these writings should not be cast adrift from the great natural philosopher and mathematician of the same name. In Priest of Nature, I emphasised that Newton believed he was deploying rational procedures in determining both doctrinal and historical truths in religion. The same general approach that informed his work in theology also guided his research in natural philosophy; there were well-established procedures for finding truths about Nature and Scripture, and for avoiding mistaking the imaginary products of the finite human mind for what had been created by God. Whatever linked the disparate areas of Newton's intellectual interests, and however he saw his work on natural philosophy as a sacred activity, his moral being can be discerned best in his religious writings. Although he was an excellent general problem-solver, it was the need to address the most pressing religious problem of the day that was a 'duty of the greatest moment'. Newton may have been the greatest scientist that ever lived - the fons et origo of the Enlightenment, and all that - but no serious historian of his life and work can deny that he was a 'sincere Christian'. ${ }^{10}$

10 For problem-solving, see Robert Iliffe and George Smith, eds., The Cambridge Companion to Isaac Newton, 2nd ed. (Cambridge, 2016), 30. 